\title{
An uncommon cause of a benign posterior mediastinal mass in an adult
}

\author{
Vishnukanth Govindaraj, Ramya Priya Anbalagan, Ravindra Chary, Vidhyalakshmi Rangarajan \\ Department of Pulmonary Medicine, Jawaharlal Institute of Postgraduate Medical Education \& Research, Puducherry, India
}

A 63 year old homemaker with a history of diagnosed type II diabetes mellitus treated with oral hypoglycemics presented with complaints of breathlessness (mMRC grade II) that had been present for 3 months. Chest radiography showed a well-defined mass in the left upper and mid-zone with no mediastinal shift. Contrast-enhanced chest tomography (CECT) of the thorax showed a large well-defined mass with soft tissue density in the upper left hemithorax extending to the posterior mediastinum. It measured $11.3 \mathrm{~mm} \times 9.1 \mathrm{~mm}$ $\times 12.7 \mathrm{~mm}$ and extended from the level of the thoracic inlet to the level of D7 with no evidence of chest wall invasion (Figure 1A). A CT-guided core needle biopsy of the mass was done and showed sheets of haphazardly arranged benign spindle cells showing positivity to beta catenin. EMA, TTF, SMA, and CD-34 were all negative. The differential diagnosis included chest wall fibromatosis and solitary fibrous tumors of the pleura.

She underwent left posterolateral thoracotomy for resection of the mass. Intraoperatively, neural elements were attached to the mass but no chest wall invasion was noted. The resected mass $(13 \times 12 \mathrm{~cm})$ contained tumor cells which were spindle-shaped with wavy nuclei and scanty eosinophilic cytoplasm with abundant myxoid stroma, a few tiny nests, and singly scattered ganglion cells (Figure 1B). They stained positive for synaptophysin. The histopathology confirmed the findings to be that of a ganglioneuroma. After surgical intervention, the left lung expanded.

Ganglioneuromas are a distinct type of well-differentiated benign tumors comprised mainly of mature ganglion cells and schwann cells without the presence of a true capsule forming a mature spectrum of sympathetic neuroectodermal tumors [1]. The most commonly involved locations that ganglioneuromas affect include the adrenal medulla (35\%), the extra-adrenal retroperitoneum (30-35\%), and the posterior mediastinum (20\%) [2]. Under macroscopic examination, an excised mass with an attached nerve trunk may facilitate the
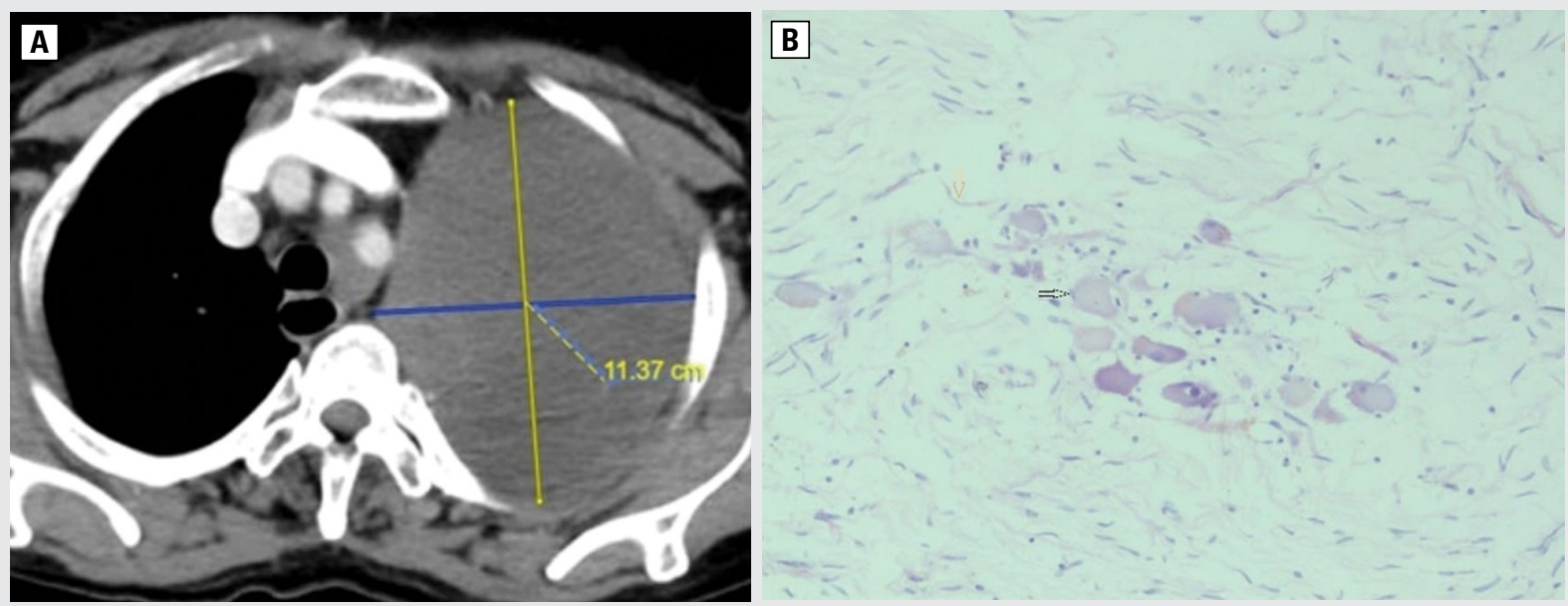

Figure 1. A. CECT of the thorax in axial view showing a large well-defined mass in the upper left hemithorax extending to the posterior mediastinum; B. Microscopic H\&E image of the specimen under $200 \times$ power showing a ganglion cell (black arrow) with Schwann cells (orange arrow) in the background of the myxoid stroma.

Address for correspondence: Ramya Priya Anbalagan, Department of Pulmonary Medicine, Jawaharlal Institute of Postgraduate Medical Education \& Research, Puducherry, India; e-mail: ramyaa2894@gmail.com

Conflict of interest: None declared

DOI: 10.5603/ARM.a2021.0048 | Received: 24.08.2020 | Copyright (C) 2021 PTChP | ISSN 2451-4934 | e-ISSN 2543-6031

This article is available in open access under Creative Common Attribution-Non-Commercial-No Derivatives 4.0 International (CC BY-NC-ND 4.0) license, allowing to download articles and share them with others as long as they credit the authors and the publisher, but without permission to change them in any way or use them commercially. 
diagnosis of a ganglioneuroma. Histologically, they are believed to originate from ganglion cells where mature ganglion cells are seen against sheets of schwann cells [3]. Total surgical resection or subtotal resection $(<2$ cms) has been observed to offer a good prognosis.

In reporting this uncommon presentation, we advise fellow clinicians to consider ganglioneuromas in the differential diagnosis in adults with a posterior mediastinal mass because it is an uncommon tumor with uncommon locations in adults.

\section{References:}

1. Joshi VV. Peripheral neuroblastic tumors: pathologic classification based on recommendations of international neuroblastoma pathology committee (Modification of shimada classification). Pediatr Dev Pathol. 2000; 3(2): 184-199, doi: 10.1007/s100240050024, indexed in Pubmed: 10679039.

2. Lonergan GJ, Schwab CM, Suarez ES, et al. Neuroblastoma, ganglioneuroblastoma, and ganglioneuroma: radiologic-pathologic correlation. Radiographics. 2002; 22(4): 911-934, doi: 10.1148/radiographics.22.4.g02jl15911, indexed in Pubmed: 12110723.

3. Enzinger MF, Weiss WS. Primitive neuroectodermal tumors and related lesions. In: Enzienger MF (editors). Soft tissue tumors. 3rd ed Mosby 1995: 928-964. 